\title{
Tests for Partial Sex-linkage in Total Color-blindness ${ }^{1}$ \\ by
}

Katumi Tanaka

National Institute of Genetics, Misima, Japan

Congenital total color-blindness, or achromatopsia, had been regarded as a typical example of autosomal, simple Mendelian recessive traits up to 1936, when Haldane described methods for the detection of a new type of human inheritance which was designated as incomplete sex-linkage or partial sex-linkage. He proposed a provisional map of the homologous segments of the $\mathrm{X}$ - and Y-chromosomes, on which were located six genes including the gene responsible for total color-blindness.

He analyzed 3 sibships of this disease by using the direct method and the crossover value was estimated at I I.4\%. He also analyzed 28 sibships by the indirect method and found the crossover value as $8.36 \%$. These were values lower than the crossover values for any others of the six partially sex-linked genes known to him. Fisher (1936) applied the tests of significance to Haldane's data and estimated the crossover values $8.12 \%$ under the assumption of complete ascertainment, $14.40 \%$ under the assumption of single ascertainment and $20.57 \%$ using ancillary information. Since then, no further study seems to have been made on the partial sex-linkage of the gene for total colorblindness.

On the other hand, Makino (I94I), Matthey (I95I) and Sachs (1954) could find no evidence of chiasma formation between the X- and Y-chromosomes and casted doubt on the existence of partial sex-linkage due to crossing over between genes located in the sex chromosomes.

The present investigation was therefore undertaken in order to examine Haldane's hypothesis on partial sex-linkage analyzing Japanese data which appeared to be suitable for such a study owing to high incidence of consanguineous matings in Japan. The cases were collected from Japanese literature and through personal communications with clinicians. The results of analyses reported in a preliminary paper (1956) will be presented here in greater detail.

\section{Analysis of sibships giving direct information}

When a gene is recessive and rare, both parents of affected children are usually phenotypically normal and heterozygous for the abnormal allele. Therefore, in order to analyze pedigrees of partially sex-linked recessive traits, it is pertinent to find whether the recessive allele is located in the $\mathrm{X}$ - or in the $\mathrm{Y}$-chromosome of the fa-

${ }^{1}$ Contribution No ${ }_{133}$ from the National Institute of Genetics, Japan. 
ther of the affected sibs. As shown by Haldane, such knowledge may be available, if the parents of the affected children are related to each other and their relationship is fully known. Namely, if the father is related to his wife through his father, it will be assumed with a high degree of probability, that he will have the allele in question in the $\mathrm{Y}$-chromosome, and if he is related to his wife through his mother, he will have it in the $\mathrm{X}$-chromosome.

Among the parents of the patients of total color-blindness in the Japanese literature, there have been reported i 7 first cousin matings, 2 second cousin matings and I half-sib mating, in which the modes of their relationship are fully known. They are given in Table I, which includes Kawakami's pedigree I (1922) cited by Haldane (1936) from Komai's monograph (1934) with the case number of 52, 9 .

As shown by Haldane, if $b$ and $d$ are the numbers of affected persons of like and unlike sexes respectively with the paternal grandparent through whom the parents are related, the estimate of crossover value is $d /(b+d)$ with information $(b+d)^{3} / b d$. Also, if a and $c$ are the numbers of normal sibs of like and unlike sexes with the grandparent above mentioned respectively, the estimate of crossover value is $(2 a-c) /(a+c)$, with information $(\mathrm{a}+\mathrm{c})^{3} / 9 \mathrm{ac}$. The classification $\mathrm{a}, \mathrm{b}, \mathrm{c}$ and $\mathrm{d}$ are listed at the top of Table $\mathrm{I}$.

The total data give

$$
\mathrm{a}=26, \quad \mathrm{~b}=29, \quad \mathrm{c}=32, \quad \mathrm{~d}=18 .
$$

Hence from $b$ and $d, x=0.3830, i=198.89$ and from $a$ and $c, x=0.344^{8}, i=26.06$, where $x$ is the estimate of the crossover value and $i$ the amount of information. Combining these figures we have $\mathrm{x}=0.3786 \pm 0.0667$. This is in the right direction for the hypothesis of partial sex-linkage, but the deviation from 0.5 is only 1.82 times standard error, being not significant.

Omitting Hoki's pedigree I and Yamanaka's pedigree, in which the parents of the patients are cousins related through the father's father, but also related more remotely through the father's mother, the remaining data give

$$
\mathrm{a}=24, \quad \mathrm{~b}=25, \quad \mathrm{c}=29 . \quad \mathrm{d}=16,
$$

whence the estimates are, from $b$ and $d, x=0.3902, i=I 72.30$ and from a and $c$, $\mathrm{x}=0.35^{85}, \mathrm{i}=23.77$ and combining them, $\mathrm{x}=0.3864 \pm 0.07 \mathrm{r} 6$. The deviation also is in the right direction, but not significant.

Macklin (1944) pointed out in her data on xeroderma pigmentosum that, though there were more males affected among sibships in which the father was related to his wife through his father ( "paternal " group) and more females affected among sibships in which the father was related to his wife through his maternal line (" maternal " group) in agreement with the expectation of the hypothesis of partial sexlinkage, but also an excess of normal males over normal females was found in the « paternal » group, and an excess of normal females in the «maternal " group. This tendency was shown more strongly in her data published in $195^{2}$ compiling Ig sibships. Namely, she found 43 males (27 normal and 16 affected) contrasting to $23 \mathrm{fe}-$ males ( 5 normal and 8 affected) in the "paternal » group, and i 7 females ( 8 normal and 9 affected) versus only ro males ( 5 normal and 5 affected) in the " maternal » 
Tab. I - Material for direct analysis

(Sibships in which modes of relationship of the parents are fully known)

a) Sibships in which the father of the patients is related to his wife through his father

\begin{tabular}{|c|c|c|c|c|c|c|c|}
\hline \multicolumn{2}{|l|}{ Author } & $\begin{array}{c}\text { Size } \\
\text { of sibship }\end{array}$ & $\begin{array}{c}\text { Normal } \\
\text { males }\end{array}$ & $\begin{array}{c}\text { Affected } \\
\text { males }\end{array}$ & $\begin{array}{l}\text { Normal } \\
\text { females }\end{array}$ & $\begin{array}{l}\text { Affected } \\
\text { females }\end{array}$ & $\begin{array}{l}\text { Relationship } \\
\text { of parents } 1\end{array}$ \\
\hline & & & (a) & (b) & (c) & (d) & \\
\hline Kawakami II & '27 & 6 & 3 & 2 & I & 0 & I (I) \\
\hline Hirota & '27 & 3 & 2 & o & o & I & I $(I I I)$ \\
\hline Kondo & $3 \mathbf{I}$ & 8 & 3 & 2 & I & 2 & I (III) \\
\hline Kondo & $3^{I}$ & 5 & $\mathbf{I}$ & I & 2 & I & $\mathbf{I}(\mathbf{I})$ \\
\hline Kondo & ${ }^{\prime} 3^{I}$ & 4 & I & I & 2 & o & I $(\mathrm{I})$ \\
\hline Yamanaka & '34 & 7 & 1 & 3 & I & 2 & I $(I)$ \\
\hline Kojima & 36 & 5 & o & I & 3 & I & I $(\mathbf{I})$ \\
\hline Aso & $3^{6} 6$ & 7 & 2 & 2 & $\mathbf{I}$ & 2 & I $(\mathrm{III})$ \\
\hline Hoki I & $3^{8}$ & 4 & I & I & 2 & o & $\mathbf{I}(\mathrm{I})$ \\
\hline Otsuka & 39 & I & o & I & o & o & 2 \\
\hline Otsuki & '4I & 5 & o & I & 2 & 2 & I (III) \\
\hline Hitomi & '43 & 7 & I & 3 & 2 & $\mathbf{I}$ & $\mathrm{H}$ \\
\hline To & & 62 & 15 & I 8 & 17 & 12 & \\
\hline
\end{tabular}

b) Sibships in which the father of the patients is related to his wife through his mother

\begin{tabular}{|c|c|c|c|c|c|c|}
\hline Author & $\begin{array}{c}\text { Size } \\
\text { of sibship }\end{array}$ & $\begin{array}{c}\text { Normal } \\
\text { female }\end{array}$ & $\begin{array}{l}\text { Affected } \\
\text { females }\end{array}$ & $\begin{array}{c}\text { Normal } \\
\text { males }\end{array}$ & $\begin{array}{c}\text { Affected } \\
\text { males }\end{array}$ & $\begin{array}{l}\text { Relationship } \\
\text { of parents } 1\end{array}$ \\
\hline & & (a) & (b) & (c) & (d) & \\
\hline Kawakami I '22 & 7 & $\mathrm{r}$ & 4 & 2 & 0 & I (IV) \\
\hline Kawakami IV '27 & 5 & I & 2 & 2 & o & I $($ IV $)$ \\
\hline Kawakami V '27 & 2 & o & o & I & I & I $($ IV) \\
\hline Hoki II $\quad{ }^{3}{ }^{8}$ & 5 & 2 & o & 2 & I & 2 \\
\hline Hoki IV & 5 & I & o & 2 & 2 & I (II) \\
\hline Azuma & 6 & I & 2 & 2 & I & I (IV) \\
\hline Otsuka & 7 & 2 & 3 & 2 & 0 & I $($ IV $)$ \\
\hline Oguchi & 6 & 3 & o & 2 & $\mathbf{I}$ & I (IV) \\
\hline Total & 43 & I I & I I & I 5 & 6 & \\
\hline
\end{tabular}

1 Abbreviations of parental relationship are as follows; 1 , first cousins: 2, second cousins: H, half-sibs. In the four types of first-cousin mating the wife is related to her husband as follows;

Type I. She is his father's brother's daughter.

Type II. She is his mother's sister's daughter.

Type III. She is his father's sister's daughter.

Type IV. She is his mother's brother's daughter. 
group. The deviation of the sex ratio from equality is significant at the $2 \%$ level in the former group and insignificant $(0.20>\mathrm{P}>0.10)$ but in the right direction in the latter. Thus, questions were presented that more males might be found affected merely because there were more males than females produced in one group and more females might be affected because there were more females than males produced in the other group.

In the data on total color-blindness, however, such an extreme unequality of sex incidence is not demonstrable. Namely, there are 33 males ( 5 normal and i 8 affected) versus 29 females ( 17 normal and I 2 affected) when the parents are related through father's paternal line, and 2 I males (I5 normal and 6 affected) versus 22 females (I I normal and I I affected) when the parents are related through father's maternal line, being in almost equality.

\section{Analysis of sibships giving indirect information}

Complete sibships, in which relationship of parents is not fully known, are analyzed by using the indirect method. From the data were excluded several families, namely, the sibships including Kajiwara's pedigree (I927, cited by Haldane with the case number 53,2), which are not complete and those including Nakamura's pedigree (1924, case number 53,8 ) in which the diagnosis was doubtful, since the patients were devoid of all the cardinal symptoms such as amblyopia, photophobia and nystagmus. Thus, there remain 26 sibships available for study. They are analyzed according to Finney's procedure (1940). Their mating type is equivalent to Finney's Type I I, since the husband is doubly heterozygous for the sex-chromosomes and the recessive abnormal allele in question, and the wife is heterozygous for the abnormal allele, but homozygous for the sex-chromosomes. Since it seems reasonable to assume that these data more closely approximate single selection than any other form of ascertainment, Finney's first scoring system is to be used. There are good evidences for almost all sibships that each sibship was independently ascertained but once.

If the children are distributed among the four classes, (a) normal females, (b) affected females, (c) normal males and (d) affected males according to the phenotypes, then the linkage score for each sibship will be given by the following formula:

$$
\lambda=\frac{\mathrm{r}}{\mathrm{I} 8}\left\{(\mathrm{a}-3 \mathrm{~b}-\mathrm{c}+3 \mathrm{~d})^{2}-(\mathrm{a}+9 \mathrm{~b}+\mathrm{c}+9 \mathrm{~d})\right\}
$$

The quantity of information $*$ is given by the following formula:

$$
x=\frac{\mathrm{I}}{\mathrm{r} 8}(\mathrm{~s}-\mathrm{I})(\mathrm{s}-4) \text {, }
$$

where $\mathrm{s}$ is the size of sibships. Actual figures of $x$ can be read from Finney's Table 3 .

The details on the sibships and computations for this linkage test are set out in full in Table 2.

The total score from the 26 sibships is:

$$
\mathrm{S}(\hat{\lambda})=+15.55554 \text {. }
$$


Tab. 2 - Indirect Analysis

\begin{tabular}{|c|c|c|c|c|c|c|c|c|}
\hline Author & & $\begin{array}{l}\text { Normal } \\
\text { female }\end{array}$ & $\begin{array}{l}\text { Affected } \\
\text { female }\end{array}$ & $\begin{array}{l}\text { Normal } \\
\text { male }\end{array}$ & $\begin{array}{c}\text { Affected } \\
\text { male }\end{array}$ & $\lambda$ & $x$ & Parents ${ }^{2}$ \\
\hline Ishihara I & $\log$ & $o$ & I & I & 0 & +0.33333 & 0.33333 & $\mathrm{R}$ \\
\hline Ishihara II & io & $\mathbf{I}$ & 2 & I & 0 & +0.88889 & I. 33333 & I \\
\hline Shoji & 18 & 4 & 2 & I & o & -0.77778 & 2.66667 & I \\
\hline Mukai & 20 & 1 & 2 & I & 0 & +0.88889 & I. 33333 & I \\
\hline Maeda I & 25 & I & o & 0 & 2 & +1.66667 & 0.77778 & I \\
\hline Ibid. & & 2 & I & 0 & 0 & $-0.5555^{6}$ & 0.77778 & I \\
\hline Ibid. & & I & I & 2 & 2 & $\ldots-1.66667$ & $2.7777^{8}$ & $11 / 2$. \\
\hline Kagoshima & '26 & 2 & I & 3 & $o$ & to.IIIII & 2.77778 & I \\
\hline Kawakami III & '27 & 4 & 0 & 3 & I & o & 4.66667 & $\mathbf{U}$ \\
\hline Niimi & 27 & 2 & 0 & $o$ & I & $+0.7777^{8}$ & $0.7777^{8}$ & $:$ \\
\hline Hirota & 27 & o & 1 & 3 & o & +1.33333 & 1.33333 & $\mathrm{U} ?$ \\
\hline Nakamura & 28 & 4 & I & 0 & 2 & $+\mathrm{I}$ & 3.66667 & I \\
\hline Oguchi & '29 & 0 & 0 & $\mathbf{I}$ & 2 & +0.33333 & $0.7777^{8}$ & I \\
\hline Makiuchi & $3^{\prime}$ & o & o & I & I & -0.33333 & 0.33333 & $\mathrm{R}$ \\
\hline Kondo & 3 I & 0 & 0 & I & I & -0.33333 & 0.33333 & $\mathrm{R}$ \\
\hline Shindo & $3^{2}$ & 2 & 2 & 3 & I & - 0.88889 & 4.66667 & 3 \\
\hline Fukushima & 34 & 3 & 0 & I & 2 & +2.33333 & $2.7777^{8}$ & 1 \\
\hline Naraki & 36 & 2 & $o$ & 2 & 4 & +5.77778 & 4.66667 & $U$ \\
\hline Miwa & 37 & 2 & $o$ & I & I & +0.22222 & I. 33333 & I \\
\hline Sato & $3^{\prime}$ & I & I & $\circ$ & 1 & -1 & $0.7777^{8}$ & $\mathrm{U}$ \\
\hline Otsuka & "39 & 5 & I & I & o & -0.77778 & 3.66667 & I \\
\hline Komoto & 40 & 1 & 0 & 3 & I & -0.66667 & 2.00000 & U \\
\hline Kato I & 40 & I & $o$ & o & I & +0.33333 & 0.33333 & $U$ \\
\hline Kato II & 40 & 7 & $o$ & o & I & +4.66667 & 4.66667 & $\mathrm{U}$ \\
\hline Seike & 42 & I & 0 & 4 & 3 & +0.22222 & 4.66667 & $\mathrm{U}$ \\
\hline Kawabata & 49 & 1 & 0 & 0 & 2 & $\begin{array}{r}+1.66667 \\
\end{array}$ & 0.77778 & $\mathrm{U}$ ? \\
\hline Total & & 48 & 16 & 33 & 29 & + I 5.55554 & 56.00002 & \\
\hline
\end{tabular}

The total information $\mathrm{S}(x), 56.00002$, is the variance of the score. Therefore, the standard error is

whence $\mathrm{t}=\mathrm{I} 5.55554 / 7.483=2.08$,

$$
\{\mathrm{S}(\boldsymbol{x})\}^{1 / 2}=7 \cdot 483
$$

which corresponds to a probability lower than $\mathrm{I} .9 \%$, thus being significant.

The estimate of the recombination value is given by

whence we obtain $\mathrm{x}=0.23^{6} 5$.

$$
\mathrm{x}==\frac{\mathrm{I}}{2}\left\{\mathrm{I}-\left(\frac{\mathrm{S}(\lambda)}{\mathrm{S}(\boldsymbol{x})}\right)^{1 / 2}\right\}
$$

2 Abbreviations for different types of parental relationship are; 1 , first cousins; $1 \frac{1}{2}$, first cousins once removed; 3 , third cousins; $R$, related; $U$, unrelated. 


\section{Discussion}

The results from the two sets of linkage tests are in the right direction for partial sex-linkage, though they differ in the estimated crossover value and in the degree of significance, thus Haldane's hypothesis seems to be supported so far as the data indicate.

It is to be noticed that the crossover value obtained by using the direct method is much higher than the value given by the indirect method. A similar tendency is seen in the data of xeroderma pigmentosum collected by Macklin (1944, 1952). She estimated the crossover value of the gene responsible for this disease at $33.3 \%$ and $35.7 \%$ based upon the direct information, while the present author obtained values $18.2 \%$ and $\mathrm{I} 6.0 \%$ by using the indirect method, i.e. Finney's first and second systems respectively based upon Macklin's I05 sibships.

Haldane (1936) has pointed out that the information to be used in the direct method is liable to errors which do not affect the indirect method. Among them, the following two factors may tend to produce higher estimates of crossover values: firstly, the information about ancestor is by hearsay, and secondly, since a large proportion of such cases are obtained from highly inbred village communities, the parents are more likely than average pair to be related by some other chain of ancestors. However, as to whether these possibilities can adequately account for the differences observed between the estimates or not the decision must be deferred until more extensive data are at hand.

\section{Summary}

Data on congenital total color-blindness were collected from the Japanese literature and through private communication, and tested for partial sex-linkage. Twenty sibships derived from consanguineous marriages, in which mode of relationship of the parents was fully known, were analyzed by using the direct method, and the crossover values $37.9-39.0 \%$ were found. Remaining 26 complete sibships were analyzed by using the indirect method, and a crossover value of $23.7 \%$ was obtained.

The higher recombination value derived from the direct method may possibly due to inaccurate information about paternal genotypes. 


\section{References}

Finnex, D. J.: 1940. The detection of linkage. Annals of Eugen. 10; I 7 I-2 14.

Fisher, R. A.: 1936. Tests of significance applied to Haldane's data on partial sex-linkage. Annals of Eugen. $7 ; 87-104$.

Haldane, J. B. S.: 1936. A search for incomplete sex-linkage in man. Annals of Eugen. 7; 28-57.

Komar, T.: 1934. Pedigrees of Hereditary Diseases and Abnormalities Found in the Japanese Race. Maruzen Co. Tokyo.

Macklin, M. T.: 1944. Xeroderma pigmentosum. Report of a case and consideration of incomplete sex linkage in inheritance of the disease. Arch. Derm. Syph. 49; I57-I 7 I.

Macklin, M. T.: 1952. Sex ratios in partial sex-linkage. I. Excess of affected females from consanguineous matings. Am. Jour. Human Genet. 4; I $4-30$.

Makino, S.: 194I. Studies on the murine chromosomes. I. Cytological investigations of mice, included in the genus Mus. Jour. Fac. Sci. Hokkaido Univ. VI, 7; 305-38o.

Matthey, R.: 1951. The chromosomes of the vertebrates, in Advances in Genetics, IV, edited by Demerec, M. Acad. Press, New York.

SACHs, L.: 1954. Sex-linkage and the sex chromosomes in man. Annals of Eugen. $18 ; 255^{-162 .}$

TANAKA, K.: 1956. Tests for partial sex-linkage in achromatopsia. Annual Report from the National Inst. of Genetics, 6 (in press). 


\section{SOMMARIO}

Dalla bibliografia giapponese e direttamente si sono raccolti dati sulla acromatopsia totale, dati che sono stati controllati per un parziale sex-linkage.

\section{ZUSAMMENFASSUNG}

In der japanischen Literatur gefundene Angaben über angeborene totale Farbenblindheit sind auf partielle geschlechts-gekoppelte Vererbung geprüft worden. 20 Sippenschaften aus bluts-
Venti fratrie derivate da matrimoni fra consanguinei, in cui il modo di parentela dei genitori era esattamente noto, sono state analizzate usando il metodo diretto, e si sono trovati dei valori di crossover del 37,9-39,0\%. Le rimanenti 26 fratrie complete

verwandten Ehen stammend, in denen die Verwandtschafts-beziehungen klargestellt waren, sind mit Hilfe der direkten Methode analysiert worden, wobei die Austauschwerte $37.9-39 \%$ gefunden wurden.

Andere 26 vollständige Sip- sono state analizzate usando il metodo indiretto, e si è ottenuto un valore di crossover del $23,7 \%$.

Il più alto valore di ricombinazione derivato dal metodo diretto può forse essere dovuto ad informazioni non accurate sui genotipi paterni.

penschaften sind mit der indirelten Methode geprüft worden, wobei der Austauschwert $23.7 \%$ gefunden wurde. Die höheren Austauschwerte im ersteren Fall sind vielleicht auf ungenaue $\mathrm{An}$ gaben über die elterlichen Genotypen zurückzuführen. 